\title{
CLASSROOM ACTIVITIES TO PROMOTE STUDENTS' LITERACY DEVELOPMENT
}

\author{
Diyah Ayu Rizqiani \\ Islamic University of Riau, Pekanbaru, Indonesia \\ email: diyah@riziqiani.com
}

\begin{abstract}
Literacy leads students to academic success. The power of literacy does not only lie in the person's ability to read and write, but also in the person's capacity to apply these skills effectively for connecting, interpreting, and discerning the intricacies of the world. The purpose of this study was to describe various learning activities in grade one Ellipse Class. The study was descriptive, in which the researcher described the phenomena in the setting without attempting to make inferences or causal statements. The study was conducted at Budi Mulia Dua Pandeansari Elementary School in Yogyakarta. The instruments of this study were observation sheets, documentations, and interview protocols. The participants of this study were ten students and two classroom teachers of Ellipse Class. The results show that there are interactive activities which are able to promote students' literacy development such as reading activities, diary writing, project-based activities, and story writing.
\end{abstract}

Keywords: classroom activities, literacy skills, student literacy

\section{KEGIATAN DI KELAS UNTUK MENUNJANG PENGEMBANGAN LITERASI SISWA}

\begin{abstract}
Abstrak
Literasi mendorong kesuksesan akademis siswa. Kekuatan literasi tidak hanya terletak pada kemampuan sesesorang untuk membaca dan menulis, tetapi juga terletak pada kemampuan seseorang untuk menggunakan ketrampilanketrampilan ini secara efektif untuk menghubungkan, menginterpretasikan, dan mengurai kerumitan dunia. Tujuan penelitian ini adalah untuk menggambarkan berbagai kegiatan di kelas yang dilaksanakan di Kelas Satu Ellipse. Penelitian ini merupakan penelitian deskriptif, peneliti mendeskripsikan fenomena di lapangan tanpa berusaha mencampuri fakta yang terjadi di lapangan. Penelitian ini diadakan di SD Budi Mulia Dua Pandeansari Yogyakarta. Dalam penelitian ini, peneliti menggunakan berbagai instrumen diantaranya lembar observasi, dokumentasi, dan pedoman wawancara. Subjek penelitian ini adalah sepuluh siswa kelas satu Kelas Ellipse. Hasil penelitian menunjukkan bahwa ditemukan berbagai kegiatan interaktif di kelas yang dapat menunjang perkembangan literasi siswa diantaranya kegiatan membaca, menulis buku harian, kegiatan berbasis projek, dan kegiatan menulis cerita.
\end{abstract}

Kata Kunci: Kegiatan di kelas, ketrampilan literasi, dan literasi siswa 


\section{INTRODUCTION}

Literacy is one of the important parts in education. It leads students to academic success. Literacy is more than the ability to read and write; it is one of the best predictors of educational and life skill competencies. Early literacy skills begin early as young children learn to use verbal and non-verbal communication patterns. Furthermore, literacy development, the issue which is very closely related to reading habit, is highly correlated with school achievements. As teachers can inspire children to read, write, and learn through thoughtful planning and developmentally appropriate literacy instruction (Neuman et.al, 2000), childhood educators need to make conscious efforts to optimize children condition to acquire positive attitudes, skills, and knowledge about language and literacy.

Since our country has moved forward into the learning society, literacy might become an important issue in Indonesia. The government has released many policies and regulations in order to establish the learning society. One of the regulations and policies is about improving reading habits of Indonesian people. A study conducted by John Miller (2016) put Indonesia in the second-lowest rank of 61 measurable countries for its literate behavior characteristics.Basically Indonesian people are not a reading society. They prefer talking to reading. Televison, internet and video games have made them away from reading printed books. Students usually read books only for the fulfilment of their school assignments. As a matter of fact, the responsibility of literacy development of Indonesian people fall on the family and educators. Parents must make their children have pleasurable experience with books and stories which can build strong foundation of reading. Also, the educators must create learning activities which are able to shape the children's literacy development.

In the current study, the researcher attempts to investigate this underpinning question: What kinds of classroom activities are able to promote students literacy skills? The objectives of this study are identifying the classroom activities for promoting students literacy development. The findings of this study will be valuable for educators to improve students' literacy skills by using classroom activities.

The researcher found two research studies examining the students' literacy development. First, Nurfatimah (2015) in her paper "Developing Literacy Skills through Learning Products in English for Young Learners" provided a review of related literatures on classroom activities to develop students' literacy. Second, Julie A. Antilla (2013) in her thesis "The Effect of Early Literacy Development on Academic Success in the Educational Setting and Implications for Educational Leaders and Teachers" proposed some factors which affect literacy development and recommendations for the teachers and leaders in order to support the literacy needs for all students. 


\section{Literacy Skills and Young Learners}

National Association for the Education of Young Children (NAEYC) defines young learners aschildren aging 0-8 year-old, they are actively engaged in the daycare, family child care home, pre-school, kindergarten, and elementary school. The world of the young learnersis based on games and fun activity. They do not realize that they are learning communication, lexicon, and grammar. Teachers can use this fact to teach foreign language by using songs, games, and stories.Furthermore, young learners undergo the process of learning first, second, or foreign language literacy skills at the same time with learning English. Linse (2005) stated that L1 literacy leads to L2 literacy development awareness. Reading builds on oral language level and become the key factor that influence L2 reading skill development which includes the ability to comprehend and use both listening and speaking skills.

The term literacy has been redefined since there are global changes in the society. Cameron (2001:123) divided literacy into traditional, social, and cognitive dimensions. Traditionally, literacy is related to the two language skills; reading and writing. Socially, literacy gives opportunities to the people to share information across time and space. Cognitively, literacy requires people to use specific knowledge and skill about how the written language operates in the processing text. A recent definition of literacy was proposed by Organization for Economic Co- operation and Development (OECD): literacy is more than just reading, writing, and numeracy. Wider than that, it is related to having adequate skills for today's demands. In addition UNESCO defines literacy as the ability to identify, understand, interpret, create, communicate, compute, and use printed and written materials associated with varying contexts. Literacy involves a continuum of learning in enabling individuals to achieve their goals, to develop their knowledge and potential, and to participate fully in their community and wider society.

Experts classified some expected literacy development progresses on young learners on these various areas: (1) a sense of reading and writing works, (2) understanding and using writing and reading for specific purposes, (3) reading aloud fluently and with expression, (4) gathering information from variety of sources, and (5) reading and writing to suit different purposes (Puckett and Black, 2000 in Mc. Kay (2006:12)).Similarly, Lems et.al (2010:3) listed some key features of young learners' literacy developmental progress. They are (1) Sound-symbol matching, (2) Word recognition, (3) Vocabulary knowledge, (4) Punctuation and spelling, (5) Awareness of the diverse purpose of print, and (6) Writing for different purposes.

Literacy skills are all skills needed for reading and writing (Philips, 2003). They include such things as awareness of the sounds of language, awareness of print, and the relationship between letters and sounds. Other literacy skills include 
vocabulary, comprehension, and fluency.

\section{Phonemic awareness}

Phonemic awareness is the ability to hear, identify, and manipulate individual sounds - phonemes - in spoken words. Before children learn to read the printed materials, they need to become more aware of how the sound works. Phonemic awareness is very important for children to improve their word reading and comprehension and also help students learn to spell the words.

\section{Print awareness}

Parents can encourage print awareness by exposing children to books and other reading materials from a very young age. Most of the print awareness begins at home and the child's environment. Reading to children is important in order to foster awareness and to introduce them to the letters and alphabets. Furthermore, children can acquire print awareness from environment such as road signs, milk boxes, and advertisement billboards. It is important for children to have print awareness before entering the first grade to ensure they do not struggle learning to read.

\section{Vocabulary}

Vocabulary is the collection of words which are used by a person in a conversation. There are two kinds of vocabulary; active vocabulary and passive vocabulary. Active word is the word which is used by a person regularly in speech and writing, a person can use and define the active vocabulary in contexts. On the other hand, passive vocabulary is the vocabulary known by a person whose meaning need to be interpreted through contexts.

\section{Comprehension}

Comprehension is the ability to read and understand the text. Actually reading comprehension is more than just being able to read the words; it includes the ability to draw inferences and identify pattern and clues in the text.

\section{Fluency}

Fluency is the ability to read a text accurately, quickly, and with expression. Fluency is important because it provides a bridge between word recognition and comprehension. When fluent readers read silently, they can recognize words automatically. On the other hand, readers who have not developed fluency read choppily and slowly; reading a text word by word.

\section{Classroom Activities to Develop Literacy Skills}

Teachers can design various classroom activities to help students develop their literacy skills. Murray and Christison (2011:79-80) stated that the activities should be simple, easy, orally-based, desirable, and promoting positive affective climate in the classroom. Examples of the activities are playing games involving letters and sounds, reading books together, making other creative activities while reading, and visiting library. Furthermore, the activities do not only help students develop their literacy skills, but also facilitate students to develop their multiple intelligences. In addition, 
referring to the literacy development, Murray and Christison emphasized the importance of foundational skills of reading which consist of print concepts, alphabet recognition, and phonemic awareness.

Joyce (2009) suggested picture-word inductive model for developing students' literacy skills. First, teachers show a picture, and then students 'shake out' the words. They try to identify, draw line to the picture, and produce words. Next, after seeing the words, students can say, hear, and spell. Finally, in order to follow up the activities, students can write above the word level to express their ideas, feelings, and experiences.

On the other hand, Nunan (1989:60-63) argued that activities to develop literacy skills can be parts of skill getting or skill using. Young learners can manipulate phonological and grammatical forms to be practiced and then apply what they learn to communicate the message. First, teachers give worksheets to the students. After that, students interview their classmates and write the information on the worksheets. They can obtain data outside the classroom by interviewing their families and neighbors. Next, students write simple report to convey their personal feelings. From these activities, it is expected that the students can use English as means of communication with the people around them. Furthermore, considering the characteristic of young learners who can learn by involving various sensory, there are some activities which could help them activate their visual and auditory sensory such as tracing letters of words, coloring, seeing and finding correct written texts, and listening and finding information.

\section{METHOD}

In conducting the research study, the researcher employed a descriptive research design. In this case, the researcher examined the situation, as it exists in its current state (Leedy and Ormrod (2001). Descriptive research involves identification of attributes of a particular phenomenon based on an observational basis, or the exploration of correlation between two or more phenomena. In this study, the researcher attempted to describe the classroom activities and identify the literacy development of the first grade students.

\section{Setting}

This study was conducted at Budi Mulia Dua Pandeansari Elementary School. The location of this school is in Pandeansari Yogyakarta. Budi Mulia Dua Elementary School is very famous with its motto "Belajar dengan senang, senang di sekolah". It means the students enjoy learning at school because they are not hectic with many homework and assignments. Furthemore this elementary schooluses creativity-based curriculum which do not only develop students' cognitive skills, but also their interest and talent.

\section{Participants}

The researcher used random sampling technique to choose the participants; they were five first grade students at Ellipse Class. 
Table 1: Participants of the study

\begin{tabular}{|c|c|c|c|}
\hline No. & Name & Sex & Age \\
\hline 1. & $\begin{array}{c}\text { Falisha } \\
\text { Kaifiya } \\
\text { Naureen }\end{array}$ & Female & 7 \\
\hline 2. & $\begin{array}{c}\text { M. Janitra } \\
\text { Martono }\end{array}$ & Male & 7 \\
\hline 3. & $\begin{array}{c}\text { Emile } \\
\text { Maktub } \\
\text { Tan }\end{array}$ & Female & 8 \\
\hline 4. & $\begin{array}{c}\text { Devina } \\
\text { Aisa Liong }\end{array}$ & Female & 7 \\
\hline 5. & $\begin{array}{c}\text { Fabian } \\
\text { Uwais Al- } \\
\text { Qarny }\end{array}$ & Male & 8 \\
\hline
\end{tabular}

\section{Instruments}

This study made use of three instruments, i.e. documentation, interview protocols, and observation. The researcher collected student works in order to identify the students' literacy development. In order to check the validity of the study, the researcher conducted observation. The researcher observed the learning activities to find out the students' attitude during the learning process. The last research instrument used by the researcher is open-ended interview which was meant to clarify the purposes of the classroom activities.

\section{Procedure}

The researcher conducted pre-observation in order to elicit the problems raised in the research setting. Furthermore, the researcher observed the students while they were having learning activities to know their attitude during the learning process. Finally, in order to get clear description about the students' literacy skills, the researcher collected their works in the form of weekly diary and classroom projects.

\section{FINDING AND DISCUSSION}

This section discusses the findings of the study in accordance to the research questions. The researcher identified some classroom activities which are able to promote students' literacy development namely Reading Activity, diary writing, project-based activity and story writing.

\section{Reading Activity}

Budi Mulia Dua Elementary School tries to build reading habit by integrating reading activity as part of the students' weekly learning activity. Reading activity is abbreviated as RA in the schedule. It is conducted every Monday afternoon as seen in this schedule:

Picture 1: Students Weekly Schedule

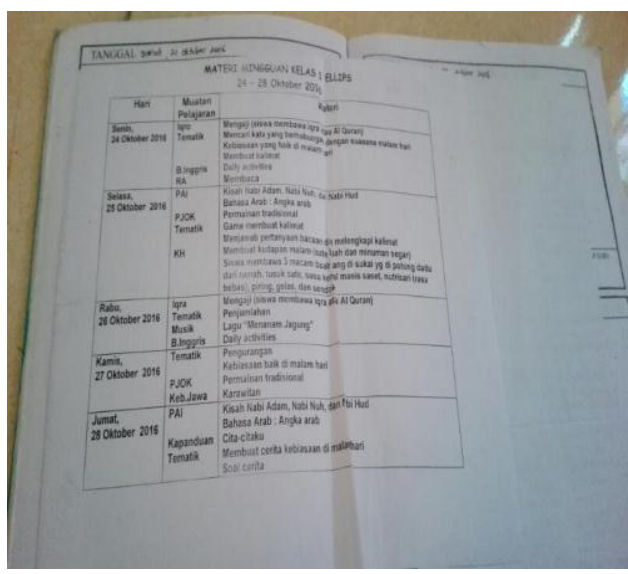

Teachers led the students to go to the library which is located in the second floor. Students were so excited, although the activity only took around 30 minutes. They went around the library to search 
interesting books. Students could find various themes in this library; comic, short story, science fiction, pop-up book, detective story, and also religious books. Most of students read the books in the library, but there are few of them decided to borrow the books and read them at home. The library has cozy reading area which is equipped with air condition.

Sometimes when the condition in the library was too crowded, the Reading Activity was conducted in the classroom. First, the teacher namely Mrs. Ansis called the name of the two students. After that, the students had opportunities to go to the library and borrow the interesting books. After the students found the books, they had to return to the classroom. Next, the teacher gave students opportunities to read the books in the classroom. During this activity, all students could ask their teachers if they found new vocabularies. Moreover, they also could share interesting information which they found on the book. For example, during the researcher's observation, she found out that one of the students namely Janitra raised his hand. He was so amazed with an astronaut who landed in the moon. He told his classmates that when he grows up, he wants to be an astronaut and goes to the other planets. Unfortunately, many students in the classroom make the classroom become so noisy. Consequently, the teacher was hard to listen when her students share interesting opinion in the classroom.

Stimulating reading habit is not easy especially for the first grade students. Since the activity held in the last session, many students felt exhausted for the all-day learning process. As a consequence, they just played around in the library. Fortunately, the teachers realized that their students were young learners whose mood always keeps changing easily. Therefore, the teachers kept motivating them to enjoy the reading activity in the library. Furthermore, the improvement of students' reading habit could be seen after having several weeks of reading activity. The students started to visit the library on the school break and before starting the class. They borrowed books and shared the stories to their friends in front of the class.

Reading habit must be introduced, inculcated, nurtured, and developed at the very young age. It is the foundation for any students to attain the academic success. Furthermore, reading habit could be developed at home and school. On other words, family and school have important roles in developing young learners' reading habit. As a matter of fact, parents faced difficulties to make their children loves reading. As stated by Palani (2012) with the advancement of technology, young learners are more prefer television and internet rather than printed books

By making reading activity as part of the learning activity, the teachers want to build student reading habit. As stated by Palani (2012), if teachers can instill and create the value of reading in children's mind, there is a possibility that they would continue reading with confidence the rest of their life. This condition eventually gives impact on students' literacy 
achievement. In addition, having reading habit would improve students' reading skills (Bignold,2003). Based on the data found during the observation, the researcher identified that the students who loves reading have broaden insight compared to those who are more prefer using electronic media.

\section{Diary Writing}

Diary writing is an individual take home assignment. Students must write their experiences about their activities on weekend in a piece of paper. This is a weekly assignment which should be submitted on Monday. The sample of student's diary is seen in the picture below:

Picture 2: Student Diary

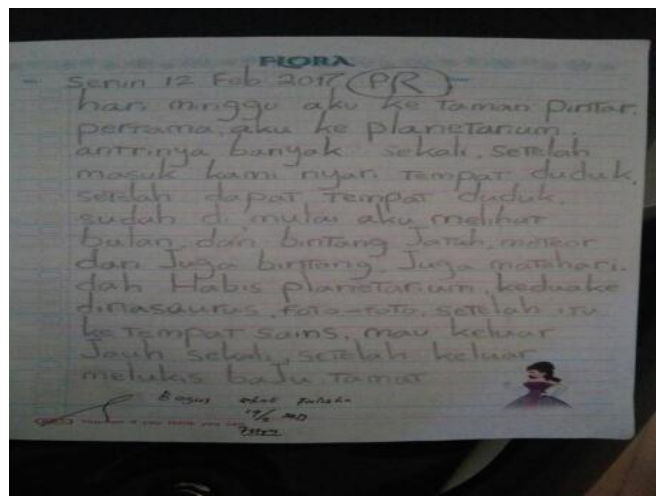

The researcher collected and analyzed students' diaries for four meetings. By analyzing students' diaries, the researcher could identify their literacy development. The researcher's observation shows that the students took several steps for writing diary. First, students memorized the activities experienced with their families on weekend. After that, they chose one activity that they would write in the diary. Then, they started writing the story.
Students faced confusion when they wrote diaries for the first time. Therefore, they could not express their ideas in a paragraph. Since they were the first grade students, they have not paid attention to the punctuation and capitalization. Also, sometimes the students did not use formal language for writing the stories. After experiencing several times writing diaries, the researcher identified some development in term of vocabulary. Students used more various vocabularies after the second assignment. Furthermore, after obtaining feedback from their teachers, students could use more formal language form.

The initial idea of diary writing activity is due to the fact that Ellipse Class students have diverse cognitive abilities. Some students could read well, but their hand writings are messy. On the other hand, there are few students who are not really able to read and write. This condition becomes the biggest challenge for the teachers. They uses diary writing as the media to help students develop their literacy skills. By writing a diary, students will learn writing and reading. Furthermore, every student must submit his or her diary every week. The students ask them to write their experience with their parents on weekend. Diary writing is free writing activity, so the teachers do not give limitation on the number of words and pages. Unlike other elementary schools, the teachers at Budi Mulia Dua Elementary School do not give score to value the students' works. They award the students by giving stamps. When 
they can write more interesting stories, they will get more stamps.

Diary writing is not only fun activity for the students, it also give many benefits for their literacy development. As stated by Absalom \& Leger (2011) that students can use diary as the media to reflect on his or her learning experience and develop their creativity. Furthermore, the study conducted by The National Literacy Trust in 2015 found out that diary writing has positive impact toward the students' attainment and also boosting their writing motivation.

Since the aim of diary writing is improving the students' writing motivation, the teachers do not correct and give feedback on the students' grammatical and lexical errors. Furthermore, the teachers give small notes written at the bottom of the page to praise the students' stories. Bagheri \& Pourgarib (2013) argue that diary usually focus on meaning rather than form where learners send message about a topic of interest to them. Similarly, teachers also do not correct the linguistic errors but respond the message in the meaningful way. So, learners have the freedom of writing without worrying the form.

By using the results of diary writing, the teachers can measure the students' abilities to read and write. Teachers give special treatment for the students who are not really able to read and write well. For students who have special needs, the teachers give extra time for reading drilling after course hour. Similarly, the teachers also provide one mentor for writing drilling during the class hour every day. The teachers continue these treatments until they find the students' literacy development.

\section{Project-Based Activity}

Project-based activity is one of the students' favorite learning activity. Every student must be creative to make a product and design it with interesting ornaments. There are two types of project-based activity; the ones as the classroom activity and the ones which become the take home assignments. The samples of students' projects are seen in this picture:

\section{Picture 3: Student' Individual Project (Mother's Day Card)}
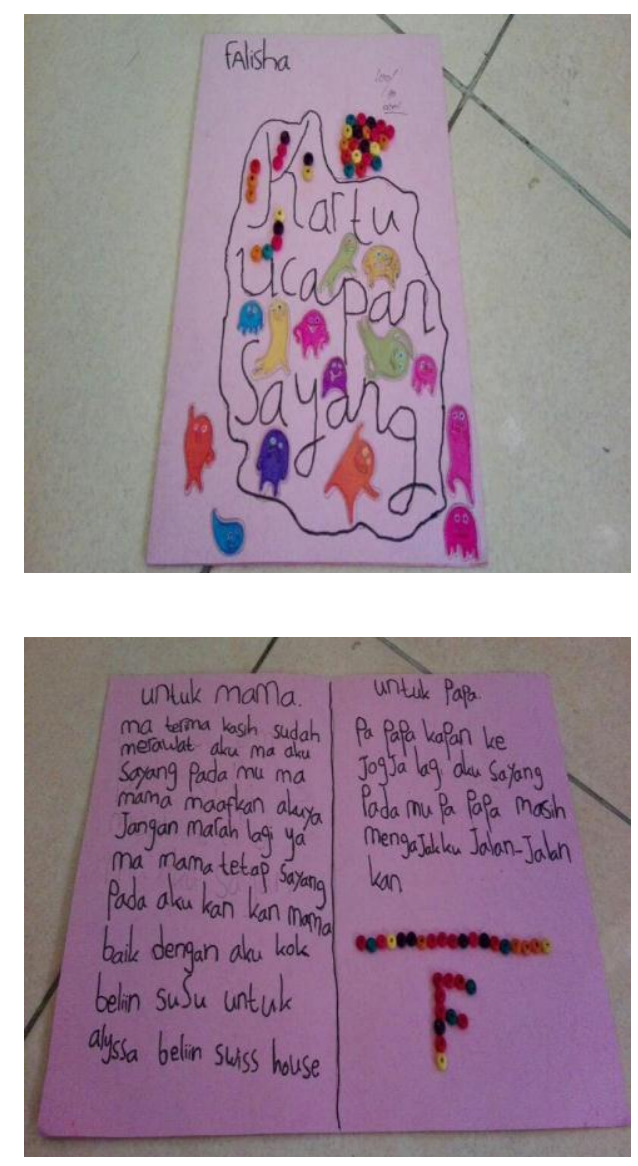

The teachers always decided the theme of every project-based 
activity. Furthermore, they asked the students to bring the ornaments and materials one day before they make the projects. Based on the researcher's observation, there were several steps for classroom projectbased activity. Since it was December, the theme of the classroom project-based activity was making Mother's Day greeting card. First, the teachers divided the students into five groups which consist of three or four students. Then, the teachers asked them to sit together with their own group. It was meant to make the teachers easier to control the students. After that, the teachers asked the students to prepare all materials; scissors, buffalo papers, beads, stickers, glitter, and glue on the table. For those who did not have complete materials, at that time some students did not bring the ornaments, so the teachers asked other students to share their ornaments with them. Next, the teachers asked students to write thankful expression for their parents on buffalo paper. The students were free to express their feeling and free to decide the shape of the greeting card. After finishing this step, the last step was giving the ornaments to make the greeting card become more interesting. Some students put glitter on the front card, while other students gave the stickers and beads in the empty area around the card.

Another type of project-based activity is the one who was done as homework. The teachers usually gave this assignment on semester break. The sample of take home project-based activity is seen in this picture:

\section{Picture 4: Take Home Project-Based} Activity

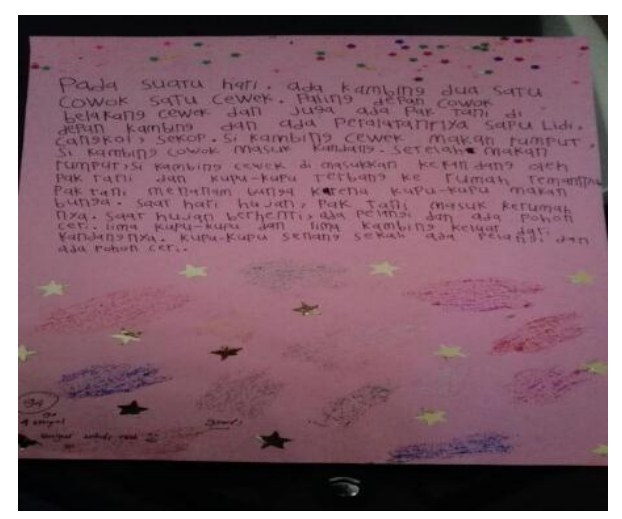

During the long holiday, the students had to write a story on a buffalo paper. Furthermore, they should make their stories attractive by giving ornaments on the buffalo paper. The sample in the picture is one of the student's works. She wrote a fable about sheep and butterfly. The researcher observed that she took some steps before making the assignment. First, the student needed to preview her background knowledge about fable story. She decided to use sheep, butterfly, and fisherman as the actors in her story. After that, she took a piece of paper and started writing the story. She tried to avoid making mistakes, so she wrote the story in another paper before rewriting it in the buffalo paper. Finally, the last step was decorating her story with glitters and stickers.

Since the main focus of the assessment is in the creativity aspect, the teachers do not correct the linguistic and lexical errors found in the students' works. One of the important lessons of writing short narration or story is the students 
learn to use various vocabularies and express their ideas. Therefore, the more creative the student to make the products, the more stamps that they get. The students always feel excited while making the products. They can play with colors, beads, stickers, glitters, and colorful markers.

Teaching young learners is different from teaching adults. Teachers do not only need to design fun learning activity, but also educative classroom activities. As stated by Willis (1996:24) that the students' task should have an outcome which become tangible learning evidence. Moreover learning products play significant roles. They could reflect the students' learning achievement and inform their parents what is going on in the learning process. By making the learning products, the students can develop their cognitive as well as their social competence.

\section{Story Writing}

The last classroom activity is story writing. The teachers usually conducted this activity in Thematic Course. The students must write a short passage related to the topic they learnt. Thematic Course has several different topics in one semester such as Pengalaman Masa Kecil, Pengalaman Bersama Teman, Pengalaman di Sekolah, and Pengalaman yang Berkesan. The samples of story writing worksheet are seen in these pictures:
Picture 5: Student's Stories
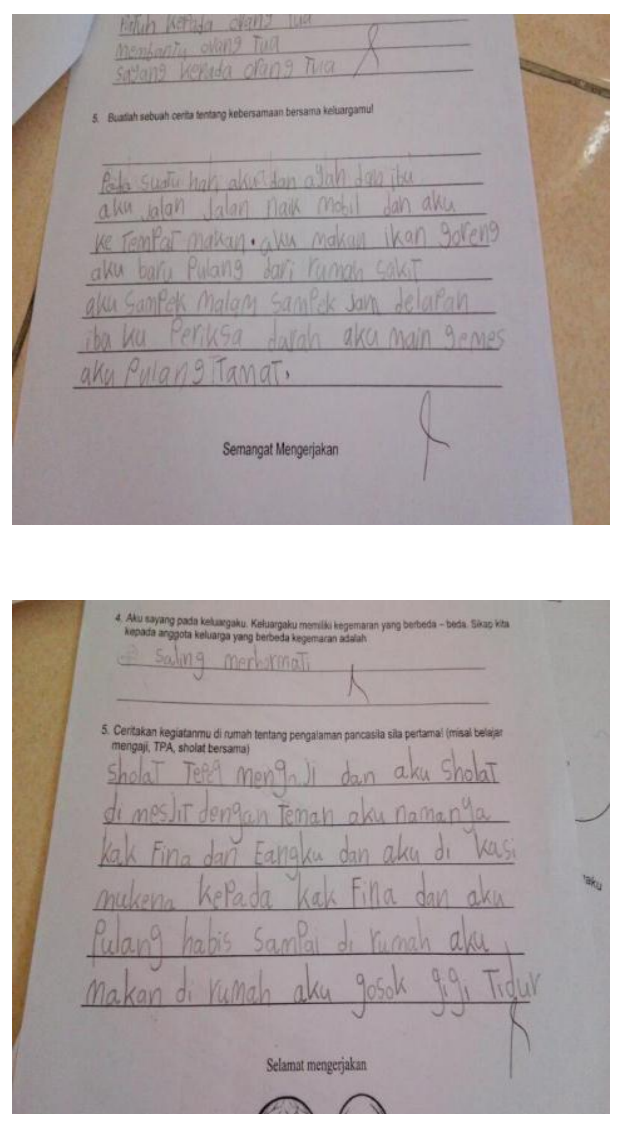

The pictures are the example of the student's stories in which the theme is Pengalaman Masa Kecil. In order to help the students, the teachers gave illustration in its instruction to make the students understand what they were going to do. Actually, the story writing also could be categorized as part of summative assessment. Furthermore, at the end of the learning process, the teachers distributed a paper and asked the students to write short passage. They had to correlate their experiences with the theme given in the paper.

Thornton \& Philip (2001) in Cakir (2004:106) stated that there are 
various activities in the classroom for teaching young learners. Those activities encourage them to explore something which is quite stimulating, motivating, and interesting. Those activities are project work, drawing, and coloring, cutting out, making things, solving problems, and recording information. Furthermore when students learn by doing, by being actively involved in their learning, it creates opportunities for them to use their imagination and creativity.

\section{CONCLUSION}

The teachers at the first grade, Budi Mulia Dua Pandeansari Elementary School, designed the classroom materials to develop students' literacy. They created many fun and educative classroom activities such as diary writing, reading activity, project-based activity, and story writing. Furthermore, it is suggested that the next researcher could conduct the study in analyzing the development of the students' literacy skills through classroom activities.

\section{REFERENCES}

Absalom, M \&Legger, D. (2011).Reflecting on Reflection: Learner Perceptions of Diaries and Blogs in Tertiary Language Study.Arts and Humanities in Higher Education. Volume 10, No.8 (pp 189-211).

Antilla, A.J. (2013). The Effect of Early Literacy Development on Academic Success in the Educational Setting and

\author{
Implications for Educational \\ Leaders and Teachers. Master \\ Thesis. Unpublished.Northern \\ Michigan University, Northern \\ Michigan.
}

Bagheri, S\&Pourgharib, B. (2013).An Investigation of the Effect of Journal Writing on EFL Learners' Oral Production.International Research Journal of Applied and Basic Sciences. Volume 4, No.10.

Bignold, H. (2003). Gender Difference and Reading. Journal of School Librarian. Volume 50. No.3 (pp 122-133).

Cakir, I. (2004). Designing Activities for Young Learners in EFL Classroom.GaziEgitimFakultie sDergisi. Volume 24. No.3 (pp 101-112).

Cameron, L. (2001). Teaching Language to Young Learners. Cambridge: Cambridge University Press.

Gunawan, S.A. (12 March 2016). Indonesia Second Least Literate of 61 Nations. The Jakarta Post. Available on http://www.thejakartapost.com/ news/2016/03/12/indonesiasecond-least-literate-61nations.html

Joyce, B. et. al. (2009).Models of Learning Tools for Teaching. Glasgow: Bell and Brain Ltd.

Leedy\&Ormrod.(2001). Practical Research Planning and 
Design. New Jersey: Pearson Merill Prentice Hall.

Lems, K. et. al. (2010).Teaching Reading to English Language Learners: Insight from Linguistics. New York: The Guilford Press.

Linse, C,T. (2005). Young Learners. USA: Mc. Graw Hill.

McKay, P. 2006. A special case for young learner language assessment in J.C. Alderson andL. F. Bachman (eds)Assessing Young LanguageLearners.

Cambridge:

CambridgeUniversity Press

Murray, D.E \&Christison. (2011). What English Language Teachers Need to Know Vol. II: Facilitating Learning. New York: Routledge.

Neuman, S. (2000).Learning to Read and Write: Developmentally Appropriate Practice for Young Children. DC: National Association for the Education of Young Children.

Nunan, D. (1989). Designing Task for the Communicative Classroom. Cambridge: Cambridge University Press.

Nurfatimah. (May 2016). Developing Literacy Skills Through Learning Product in English for Young Learners. Paper Presented in TEYLIN Conference at Ahmad Dahlan University Yogyakarta.
Palani.(2012). Promising Reading Habits and Creating Literate Social.International Reference Journal.Volume III. No.1 (pp 91-99).

Philips, L.M. (2003). Middle Grade Readers' Ability to Interpret Pragmatic Meaning.Other Ways of Seeing: Diversity in Language and Literacy. Volume 1. (pp 223-230).

Willis, J. (1996). A Framework for Task-Based Learning. Essex: Addison Wesley Longman Limited. 